\title{
The Relationship between Non-Financial Stakeholders and Capital Structure
}

\author{
Somayeh Soheilirad ${ }^{1}$, Saudah Sofian ${ }^{1}$, Abbas Mardani ${ }^{1}$, Edmundas Kazimieras Zavadskas $^{2}$, \\ Arturas Kaklauskas $^{2}$, Jafargholi Mohammadi Darvishvand ${ }^{1}$
}

${ }^{1}$ Universiti Teknologi Malaysia

Skudai, Johor 81300, Malaysia

E-mail.s_soheilirad@yahoo.com,saudah@utm.my,mabbas3@live.utm.my

${ }^{2}$ Vilnius Gediminas Technical University

Sauletekio al. 11, LT-10223 Vilnius, Lithuania

E-mail.edmundas.zavadskas@vgtu.lt,arturas.kaklauskas@vgtu.lt

cross $^{\text {ref }}$ http://dx.doi.org/10.5755/j01.ee.28.4.16812

In today's dynamic environment, both intellectual capital (IC), the main value added factor, and perceived environmental uncertainty (PEU), an unpredictable contingency factor, influence corporate performance (CP). Financial accounting literature highlights the importance of non-financial factors. Therefore, it is important for organizations to rely more on non-financial criteria than on financial factors to achieve higher competitive advantage. Identifying the most important nonfinancial factors that affect corporate performance and their relationship with capital structures (CS) is the main issue in today's dynamic conditions. This research examines the relationship between non-financial factors of IC and PEU and evaluates their influence on CS directly or indirectly by considering the mediation effects of corporate performance. Questionnaires were distributed to 339 public listed Iranian manufacturing companies selected based on census data. Data was analyzed using structural equation modeling. The main findings of this study are as follows: IC can enhance corporate performance, PEU is positively linked to corporate performance, and corporate performance is positively linked to capital structure. The results also indicated a full mediation effect of corporate performance in the relationship between PEU and capital structure. Also, we analyze intellectual capital relation with 1) traditional vs. secular-rational values and with 2) survival vs. self-expression values. In order to determine the most efficient versions of intellectual capital, an Intellectual Capital Multiple Criteria Decision Support (ICMCDS) system was developed, consisting of a database, database management system, model-base, model-base management system, and user interface. This study contributes to determining capital structure decision making by considering IC and PEU in the context of companies in Iran. Further in-depth research is needed to examine the links between non-financial factors and capital structure with different measurement and perspectives to develop a deeper understanding of their effect on capital structure.

Keywords: Corporate Performance, Intellectual Capital, Perceived Environmental Uncertainty, Capital Structure, NonFinancial Stakeholders.

\section{Introduction}

In recent decades, the choice between debt and equity is aimed to find the right capital structure to maximize shareholder wealth (Babatunde, 2016); as a result, companies try to select an appropriate mixture of financing sources and securities (Attar, 2014). A primary challenge faced by many researchers is to understand and to determine all possible factors that influence financial decisions (Mat Nawi, 2015; Attar, 2014). According to stakeholder theorists, non-financial stakeholders have a relationship with capital structure decisions (Attar, 2014). As argued by Myers and Saretto (2010), non-financial factors are customers, suppliers, competitors and employees, new entrants, governments, and regulators. Moreover, to better understand non-financial stakeholders and to determine their impact on capital structure (CS) decisions, Mat Nawi (2015) analyzed the companies' ability to adjust non-financial factors and capital structure. Recently, managers have attempted to create shareholder value by improving companies' competitive advantage through recognition of intangible assets which are known as intellectual capital (IC) (Pourkiani et al., 2014). In the history of development economics, IC performance is generally defined as the efficiency of investments in intangible resources in the process of value creation and financial performance (Survilaite et al., 2015). Human capital, relational capital, structural capital, and spiritual capital are defined as four components of IC (Ismail, 2005). Therefore, it is vital to measure IC's performance to estimate the effectiveness of value creation in companies.

Parallel to the above discussions, the global economy is becoming increasingly uncertain. Several strategic management researchers, such as Mat Nawi (2015), Attar (2014), and Aftab et al. (2012), have tried to analyze the 
effects of company structure, environment, and strategy on $\mathrm{CP}$ and CS. According to Simerly and Li (2000), environmental factors can play an important role in addressing the capital structure. Moreover, examining the relationship between contingency factors related to the companies' value and their capital structure is a relatively new and important area of strategic research (Rakshit \& Chakrabarti, 2012). Capital structure has been considered an important issue from a financial economics standpoint, as it is linked to the companies' ability to meet the demands of various stakeholders (e.g., Modigliani \& Miller, 1963). Therefore, it is important that management's effectiveness is improved by understanding how much the environmental factors affect CP. This approach is helpful because uncertain factors can significantly influence companies' chances of survival and success (Dragnic, 2014). Likewise, management can reduce their environmental impact by increasing their awareness of environmental changes (Seaman \& Williams, 2011).

Moreover, financial accounting and strategic management researchers, such as Emadzadeh et al. (2013), established that both IC performance and an organization's environmental actions play important roles in achieving sustainable competitive advantage and protecting their successful position in the marketplace. Indeed, there is a close relationship between PEU, IC, and corporate performance. Corporate performance is at the heart of our understanding of the relationship between non-financial stakeholders from internal and external environments and capital structure. In order to have a multi-dimensional view and to solve these problems, the Balance Score Card offers an integrated set of measurements that links corporate strategy and system performance to long-term financial success (Awadallah \& Allam, 2015).

Consequently, examining the influence of non-financial factors on CP from internal and external environments and their relationship with capital structure is the main issue in today's dynamic conditions. By considering the above mentioned issues and according to previous studies which used CP to determine CS, this study investigated the effect of IC and PEU on capital structure by considering the mediation effect of corporate performance. Therefore, examining the relationship between non-financial factors from internal (IC) and external (PEU) sources and evaluating their influence on capital structure directly or indirectly by considering $\mathrm{CP}$ as mediator are the main objectives of this study. The findings of this study have filled the gap regarding the effect of IC and PEU on CS by using $\mathrm{CP}$ as a mediator in Iran.

\section{Literature}

\section{The Linkage between IC and CP}

IC is an important resource and a strong driver of corporate performance and value creation (Sajedi et al., 2015; Alipour, 2012). Earlier empirical studies proved that IC components have an important and fundamental impact on corporate performance (Abdullah \& Sofian, 2012; Ling, 2013; Mehralian et al., 2013; Stephen et al., 2014). For instance, Abhayawansa and Guthrie (2014), Nimtrakoon (2015), and Meihami et al. (2014) investigated the relationship between IC and corporate performance and their results confirmed the positive relationship between IC and corporate performance. Rudez and Mihalic (2007) tested the impact of certain IC components (human capital [HC], structural capital [SC], and relational capital [RC]) on firms' financial performance in the hotel industry in Slovenia. Their findings showed that financial performance is significantly influenced by IC. In another study, Wang and Cheng (2005) showed the positive impact of IC components on overall business performance in Taiwanese IT firms. Therefore, based on the above discussions the following hypothesis was developed:

H1: There is a positive relationship between IC and corporate performance among manufacturing companies of Iran.

\section{The Linkage between PEU and IC and CP}

On investigating the role of non-financial performance in a high uncertainty environment, Ahangar et al. (2012), Ahangar (2011), and Soheilirad and Sofian (2016) claimed that non-financial measures tried to facilitate organizational actions and decisions that support strategies based on the needs of internal and external stakeholders, customers, managers, regulatory bodies, and employees in uncertain environments. Several studies e.g., Jusoh (2008), AbdelKader and Luther (2008), Elbanna and Alhwarai (2012), and Rahimnia et al. (2014) have empirically and theoretically explored the possible relationships among environment and performance in the manufacturing sectors. Furthermore, many previous studies, such as those by Galdeano-Gómez and Cespedes-Lorente (2008) and Wahba (2008), concluded that there is a positive relationship between being proactive in environmental issues and firm performance. Hence, the following research hypothesis is proposed:

H2: There is a positive relationship between a PEU and corporate performance among manufacturing companies of Iran.

There is a growing body of literature that recognizes the importance of the manager's role to oversee changes in the company's external environment by choosing an appropriate structure and design of a matching strategy (Bontis et al., 2007; Porter, 2008; Survilaite et al., 2015). According to Al-Mawali (2015) and Hoque (2005), PEU is an important aspect in several management accounting studies which found that organizational structure and PEU are closely related, and high levels of PEU are positively associated with an organization's structures. To maintain stability and to increase value, companies must formulate their strategies for IC; if the firms intend to sustain or to augment their value quotients, enrichment of ICs must be accounted (Tseng et al., 2015). Hence, the following research hypothesis is proposed:

H3: There is a positive relationship between PEU and IC among manufacturing companies of Iran. 


\section{The Linkage between CS and Non-Financial Stakeholders}

The research on capital structure from a financial strategic management perspective provides support for the argument that non-financial stakeholders may have an impact on capital structure decisions. Several review studies tried to determine the important effects of environmental factors on capital structure decisions. As argued by Mat Nawi (2015), Attar (2014), Graham et al. (2011), Hillier et al. (2008), La Rocca and La Rocca, (2007), and Myers and Saretto (2010), non-financial stakeholders and macroeconomic conditions have some influence on corporate leverage. Hence, the following research hypothesis is proposed:

H4: There is a negative relationship between PEU and CS among manufacturing companies of Iran.

On the other hand, according to Aftab et al. (2012), Liu and Wong (2011), and Newman et al. (2011), the types of assets influence the debt-equity ratio. Delcoure (2007) and Al-Ajmi et al. (2009) affirm that firms with specialized or unique products face more costs in terms of liquidation and are more likely to be less leveraged. For instance, IC as nonfinancial stakeholders from internal environment affects the dynamics of a firm's growth opportunities, technological innovations, and earnings processes ( $\mathrm{Li}$ et al., 2011). Hence, the following research hypothesis is proposed:

H5: There is a negative relationship between IC and CS among manufacturing companies of Iran.

\section{Balanced Scorecard (BSC) as Performance Measurement Method}

There are relatively few studies regarding the area of firm performance, but Soheilirad and Sofian (2016) and Kaplan and Norton (2001) concluded that managers are not likely to use traditional financial measures of performance such as net earnings or return of investment. According to Jusoh (2005), traditional performance measures are unable to reasonably reflect the influence of today's changing business environments on corporate performance. In recent years, an increasing number of literature reviews claim that because non-financial performance measures focus on a firm's long-term success factors, managers seek to improve the organization's longterm performance (Zin et al., 2013). Kaplan and Norton (2001) proposed the balanced scorecard (BSC) measurement system to organize performance into four balanced perspectives: financial, customer, internal business process, and learning and growth. Based on the literature, the following research hypotheses are proposed:

H6: There is a positive relationship between $C P$ and CS among manufacturing companies of Iran.

H7: CP has a mediating role in the relation between $I C$ and CS among manufacturing companies of Iran.

H8: CP has a mediating role in the relation between $P E U$ and CS among manufacturing companies of Iran.

\section{Research Method}

\section{Variables and Measurement}

This study requires measurement of three primary groups of variables. Based on the research framework, IC and PEU are considered as independent variables. This study adopts questionnaires from Bontis (1998) and Ismail (2005) to measure IC components (human capital, structural capital, relational capital, and spiritual capital) by using 18 items. In this study, PEU includes various aspects of companies. Suppliers, customers, competitors, deregulation, government regulatory, economics environment, industry relation, and financial market are considered as the primary PEU's indicators which include 30-item instruments adopted from Jusoh, 2008. In this study, corporate performance is considered as the mediator variable. This variable was measured based on four perspectives of BSC which includes customer perspective, internal business process perspective, learning and growth perspective, and financial perspective (Blackmon, 2008). The study employs the BSC measurement method to assess CP by adopting Blackmon's (2008) questionnaire. The BSC measures will be assessed via 20 items in the questionnaire. The respondents were asked to indicate the extent of their use of each indicator across the four dimensions using a five-point Likert-type scale. The last variable, Capital structure, a dependent variable, was measured via six questions adopted from Norton's (1991) questionnaire. The managers' views of inside and outside financing and target debt ratio were determined by these eight questions. Based on Asiaei and Jusoh (2015), this study controlled some variables: namely, firm age, size, and industry type. After completed questionnaires were returned, Structural Equation Modelling (SEM) was applied to test the relationships between the variables.

\section{Sample and Data Collection}

This study selected all the manufacturing companies listed in Tehran Stock Exchange, and top level managers were selected as the respondents. In statistics, the method through which the entire population is selected for observation for the purpose of data collection is called census, and the selected number of population is known as the sample. This approach is appropriate for small populations such as reflected in this study. Sekaran and Bougie (2010) stated that the unit of analysis is determined based on the study's objective. According to the "Tehran Stock Exchange Monthly Report" (May 2012), there are 40 types of industries in ten categories that include 339 manufacturing companies listed in TSE. Questionnaires were distributed to 339 public listed Iranian manufacturing companies selected by census. In all, 339 questionnaires were distributed. Questionnaires are mailed to these companies, and the survey was carried out over the sixmonth period from January 2014 to June 2014, it took almost 6 months period. However, $51 \%(n=173)$ of the questionnaires were returned. From 173 questionnaires, 12 of them were incomplete; therefore, 161 of 339 (47.5\%) questionnaires were accepted for further processing and analysis. To evaluate possible non-response bias, ChiSquare and independent t-tests were conducted to assess the 
S. Soheilirad, S. Sofian, A. Mardani, E. K. Zavadskas, A. Kaklauskas, J. M. Darvishvand. The Relationship between Non...

difference between the two early and large groups on nominal items (i.e. industry type, firm size and age). The results of the analysis indicated that the nominal items had no significant $(\mathrm{P}>0.05)$ difference among them and that there was no significant difference between the early and late respondents in industry type, size, and age. In this study, a pilot study on a sample of 31 companies was conducted to assess the reliability of instruments through Iranian manufacturing firms. The reliability of the questions on the pilot test instrument was measured using Cronbach's alpha; in social science, a Cronbach's alpha greater than is 0.60 or higher is acceptable (Hair et al., 2014).

\section{Analysis and Results Characteristics of the Respondents}

This section describes results of the descriptive analysis of the demographic characteristics of the respondent firms' profile. All the firms that participated in this study were selected based on the industry type, number of employees, and years of operations. Table 1 reveals the frequency distribution of the firms.

Profile of the Participating Companies

\begin{tabular}{|c|c|c|c|c|c|}
\hline & Frequency & Percentage $\%$ & & Frequency & Percentage \% \\
\hline Manufacturing Sector & & & Age of Business & & \\
\hline Electrical and electronic & 23 & 14.28 & $5-10$ & 25 & 15.55 \\
\hline Iron, steel and metal & 14 & 8.69 & $10-15$ & 35 & 21.73 \\
\hline Food and beverage & 15 & 9.31 & $15-20$ & 50 & 31.05 \\
\hline Rubber and plastic & 12 & 7.45 & over 20 & 51 & 31.67 \\
\hline Paper, printing, packaging, & 20 & 12.42 & Total & 161 & 100 \\
\hline The chemicals and chemical & 20 & 12.42 & No. of Employees & & \\
\hline Pharmaceutical, medical & 21 & 13.04 & $1-250$ & 3 & 1.86 \\
\hline Furniture and wood related & 13 & 8.07 & $251-500$ & 28 & 17.39 \\
\hline Textile, clothing, footwear & 15 & 9.31 & $501-750$ & 39 & 24.22 \\
\hline Machinery and equipment & 13 & 8.07 & $751-1000$ & 41 & 25.46 \\
\hline \multirow{2}{*}{ Total } & \multirow{2}{*}{161} & \multirow{2}{*}{100} & over 1001 & 50 & 31.05 \\
\hline & & & Total & 161 & 100 \\
\hline
\end{tabular}

Based on the results in Table 1, of the 161 valid respondents, $14.28 \%$ belong to electrical and electronic industries and $7.45 \%$ belong to rubber and plastic, which is considered the smallest industry group. In terms of operation and business, the majority of the firms (31.67 $\%$ ) have been in business over 20 years and $15.55 \%$ have between 5-10 years' experience. In terms of the number of employees, the largest occupation group was $31.05 \%$ which indicates they have more than 1,001 employees; the smallest occupation group is $1.86 \%$ with 1-250 employees.

\section{Measurement Model}

There are two usual approaches to evaluate internal consistency for each construct; Cronbach's alpha and composite reliability. According to Hair et al., 2014 , composite reliability should be higher than 0.70 ). Table 2 shows the internal consistency between items and each construct.

Table 2

Measurement Model

\begin{tabular}{|c|c|c|c|c|c|}
\hline Construct & Item & Factor loading & Cronbach's alpha & composite reliability & AVE \\
\hline \multicolumn{3}{|c|}{ Intellectual capital } & 0.962 & 0.966 & 0.626 \\
\hline \multirow{4}{*}{ Human capital } & Hc1 & 0.7968 & \multirow{4}{*}{0.823} & \multirow{4}{*}{0.884} & \multirow{4}{*}{0.661} \\
\hline & $\mathrm{Hc} 2$ & 0.6215 & & & \\
\hline & $\mathrm{Hc} 3$ & 0.9043 & & & \\
\hline & $\mathrm{Hc} 4$ & 0.8982 & & & \\
\hline \multirow{5}{*}{ Relational Capital } & Rc1 & 0.6065 & \multirow{5}{*}{0.841} & \multirow{5}{*}{0.890} & \multirow{5}{*}{0.631} \\
\hline & Rc2 & 0.8623 & & & \\
\hline & Rc3 & 0.4805 & & & \\
\hline & Rc4 & 0.9085 & & & \\
\hline & Rc5 & 0.8329 & & & \\
\hline \multirow{4}{*}{ Structural Capital } & Sc1 & 0.7576 & \multirow{4}{*}{0.822} & \multirow{4}{*}{0.882} & \multirow{4}{*}{0.655} \\
\hline & Sc2 & 0.8278 & & & \\
\hline & Sc3 & 0.6210 & & & \\
\hline & $\mathrm{Sc} 4$ & 0.9178 & & & \\
\hline \multirow{5}{*}{ Spiritual capital } & Spc1 & 0.6085 & \multirow{5}{*}{0.899} & \multirow{5}{*}{0.927} & \multirow{5}{*}{0.723} \\
\hline & $\mathrm{Spc} 2$ & 0.9214 & & & \\
\hline & $\mathrm{Spc} 3$ & 0.9089 & & & \\
\hline & Spc4 & 0.9214 & & & \\
\hline & Spc5 & 0.7285 & & & \\
\hline \multicolumn{3}{|c|}{ Corporate performance } & 0.805 & 0.865 & 0.570 \\
\hline \multirow{4}{*}{ Business perspective } & Bp1 & 0.8979 & \multirow{4}{*}{0.879} & \multirow{4}{*}{0.917} & \multirow{4}{*}{0.737} \\
\hline & $\mathrm{Bp} 2$ & 0.7617 & & & \\
\hline & $\mathrm{Bp} 3$ & 0.9243 & & & \\
\hline & $\mathrm{Bp} 4$ & 0.8416 & & & \\
\hline
\end{tabular}


Inzinerine Ekonomika-Engineering Economics, 2017, 28(4), 363-375

\begin{tabular}{|c|c|c|c|c|c|}
\hline Construct & Item & Factor loading & Cronbach's alpha & composite reliability & AVE \\
\hline \multirow{7}{*}{ Customer perspective } & Cp1 & 0.8482 & \multirow{7}{*}{0.839} & \multirow{7}{*}{0.879} & \multirow{7}{*}{0.550} \\
\hline & $\mathrm{Cp} 2$ & 0.7217 & & & \\
\hline & $\mathrm{Cp} 3$ & 0.6610 & & & \\
\hline & $\mathrm{Cp} 4$ & 0.5300 & & & \\
\hline & Cp 5 & 0.7056 & & & \\
\hline & Cp 6 & 0.8284 & & & \\
\hline & Cp7 & 0.6655 & & & \\
\hline \multirow{4}{*}{ Learning Perspective } & Lp1 & 0.7323 & \multirow{4}{*}{0.793} & \multirow{4}{*}{0.859} & \multirow{4}{*}{0.555} \\
\hline & Lp2 & 0.8741 & & & \\
\hline & Lp3 & 0.7888 & & & \\
\hline & Lp4 & 0.6175 & & & \\
\hline \multirow{5}{*}{ Financial perspective } & Fp1 & 0.6581 & \multirow{5}{*}{0.950} & \multirow{5}{*}{0.957} & \multirow{5}{*}{0.548} \\
\hline & Fp2 & 0.3782 & & & \\
\hline & Fp3 & 0.8607 & & & \\
\hline & Fp4 & 0.8316 & & & \\
\hline & Fp5 & 0.8590 & & & \\
\hline \multicolumn{3}{|c|}{ Perceived environmental uncertainty } & 0.932 & 0.949 & 0.557 \\
\hline Competitor & $\mathrm{PCo5}$ & 0.7758 & 1.00 & 1.00 & 1.00 \\
\hline \multirow{2}{*}{ Customer } & $\mathrm{PCu} 2$ & 0.8696 & \multirow{2}{*}{0.838} & \multirow{2}{*}{0.901} & \multirow{2}{*}{0.792} \\
\hline & $\mathrm{PCu} 3$ & 0.8701 & & & \\
\hline Deregulation & PD3 & 0.8647 & 1.00 & 1.00 & 1.00 \\
\hline Economic & PEco2 & 0.8274 & 1.00 & 1.00 & 1.00 \\
\hline \multirow{4}{*}{ Government } & PG1 & 0.9131 & \multirow{4}{*}{0.932} & \multirow{4}{*}{0.951} & \multirow{4}{*}{0.831} \\
\hline & PG4 & 0.8875 & & & \\
\hline & PG5 & 0.9189 & & & \\
\hline & PG6 & 0.8549 & & & \\
\hline \multirow{2}{*}{ Industrial relation } & PIR1 & 0.9268 & \multirow{2}{*}{0.845} & \multirow{2}{*}{0.928} & \multirow{2}{*}{0.866} \\
\hline & PIR3 & 0.9344 & & & \\
\hline Financial market & PF1 & 0.9268 & 1.00 & 1.00 & 1.00 \\
\hline \multirow{2}{*}{ Supplier } & PS1 & 0.8667 & \multirow{2}{*}{0.707} & 0872 & 0773 \\
\hline & PS2 & 0.8933 & & $0.8 / 2$ & 0.173 \\
\hline & tructure & & 0.911 & 0.931 & 0.693 \\
\hline & CS1 & 0.8085 & & & \\
\hline & $\mathrm{CS} 2$ & 0.8547 & & & \\
\hline & CS3 & 0.8630 & & & \\
\hline Capital structure & $\mathrm{CS} 4$ & 0.8700 & & & \\
\hline & CS5 & 0.8001 & & & \\
\hline & CS6 & 0.7946 & & & \\
\hline
\end{tabular}

Table 2 shows the composite reliability (CR), Cronbach's alpha (CA), and the average variance extracted (AVE) for reflectively-measured constructs. To meet these criteria, sixteen indicators from PEU are removed. According to Table 2's information, the criteria are met for each of these constructs; the composite reliability was higher than the recommended 0.70 . Therefore, sufficient reliability was demonstrated for all constructs because all were greater than the benchmark of 0.70 . Furthermore, the standardized factor loading was significant in this study. It reveals that convergent validity is supported for all the measurement items. In addition to convergent validity, discriminant validity is supported as well (see Table 3 ).

Table 3

Discriminant Validity

\begin{tabular}{|c|c|c|c|c|}
\hline & CS & CP & IC & \\
\hline Capital Structure & 0.832466 & & & \\
\hline Corporate Performance & 0.817277 & 0.820443 & & \\
\hline Intellectual Capital & 0.774569 & 0.759790 & 0.7913861 & \\
\hline Perceived Environmental Uncertainty & 0.464088 & 0.525992 & 0.270498 & \\
\hline
\end{tabular}

\section{Structural Model}

PLS-SEM uses a path coefficient to determine the strength and significance of the hypothesized relationships between the latent construct. These paths' coefficient can also be interpreted as standardized beta coefficients. In PLSSEM, normally bootstrapping techniques are used to calculate the t-value for the path coefficients to test the significance of hypothesized relationships (Hair et al, 2014). 


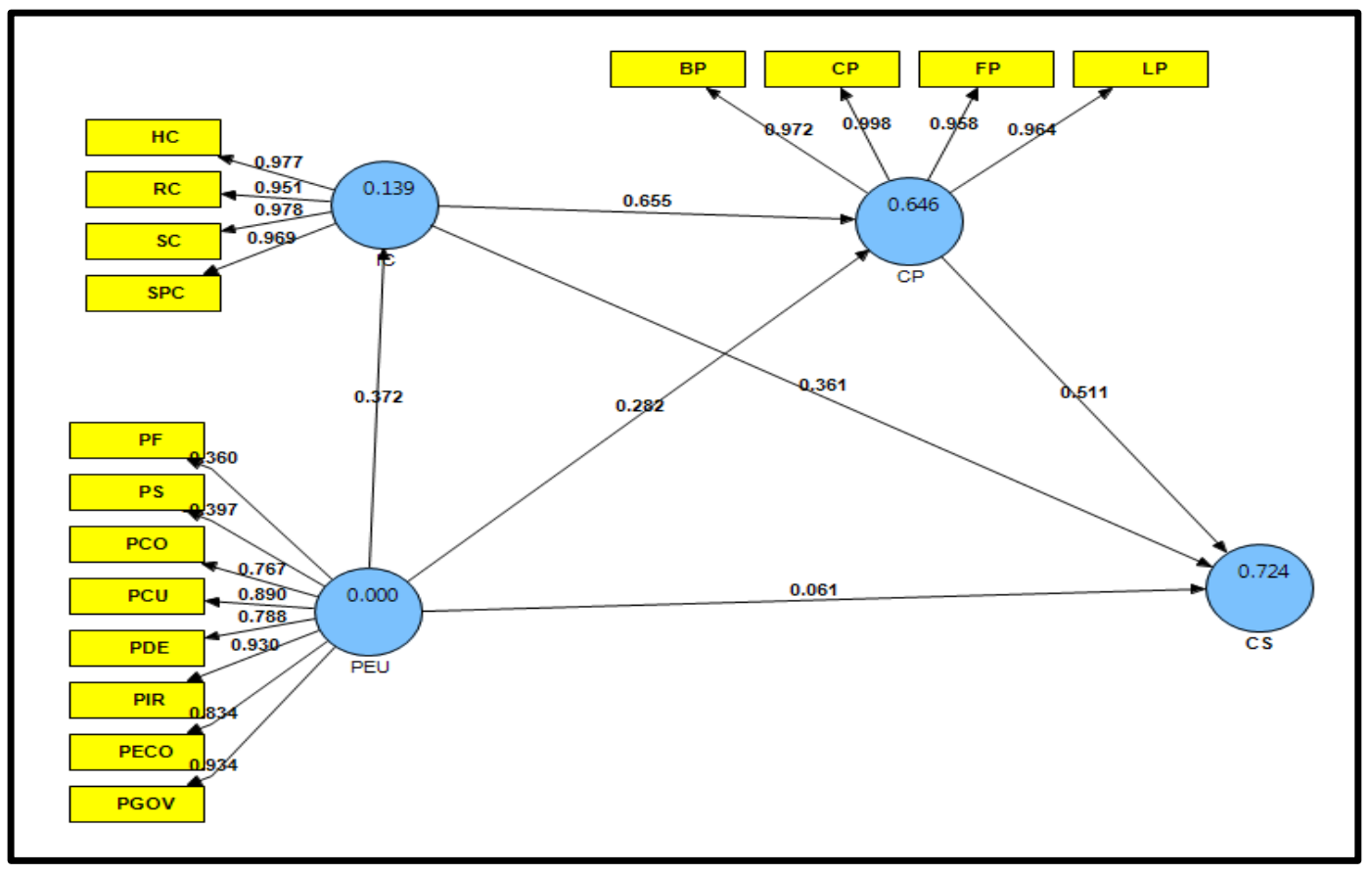

Figure1. Path Coefficient and Hypothesis Testing

For describing outcomes, this study investigated the empirical t-value and the bootstrapping confidence interval (with a sample size of 5000). Table 4 illustrates the assessment of the significance of the path coefficients of constructs of this study in terms of t-value and confidence interval. In exploratory studies, a significance level of 10 percent is often assumed (Hair et al, 2014), so this study adopted this significance level. Thus, the normally adopted critical values for two-tailed tests in this study is 1.65 (significance level=10 percent). The results show that from 6 direct hypotheses among constructs which were developed based on the literature, 5 path coefficients $(\mathrm{H} 1, \mathrm{H} 2, \mathrm{H} 3, \mathrm{H} 5$, H6) have a t-value greater than 1.65 , indicating they are statistically significant at the 10 percent level and are supported. The remaining direct hypothesis (H4) is not supported in the hypothesized sign, since its t-value is not significant (i.e., <1.65). Table 3 shows that the path coefficient for IC $\rightarrow$ CP was 0.65 and t-value 15.143; thus, $\mathrm{H} 1$ of the study has been accepted. The path coefficient for PEU -> CP was 0.28 and t-value 5.888; thus, H2 of the study has been accepted. The path coefficient for PEU -> IC was 0.372 and t-value 6.69 ; thus, $\mathrm{H} 3$ of the study has been accepted. The path coefficient for PEU -> CS was 0.060 and $\mathrm{t}$-value 1.20. Thus, $\mathrm{H} 4$ of the study has not been accepted. The path coefficient for IC -> CS was 0.36 and t-value 5.020. According to the previous study and our initial hypothesis, the negative relationship between IC and capital structure was anticipated. Therefore, H5 of the study has been not accepted. The path coefficient for CP $\rightarrow$ CS was 0.511 and t-value 5.884; thus, H6 of the study has been accepted.

Direct Hypothesis Results

\begin{tabular}{|c|c|c|c|c|c|}
\hline Hypothesis & Paths & Path co. & SD & T-Value \\
\hline H1 & IC -> CP & 0.6547 & 0.0432 & 15.540 \\
\hline H2 & PEU -> CP & 0.2822 & 0.0442 & 6.059 \\
\hline H3 & PEU -> IC & 0.3724 & 0.0553 & 6.776 \\
\hline H4 & PEU -> CS & 0.0611 & 0.0522 & 1.198 \\
\hline H5 & IC - CS & 0.3613 & 0.0449 & Accepted \\
\hline H6 & CP -> CS & 0.5112 & 0.0860 & Rejected & Rejected \\
\hline
\end{tabular}

\section{Mediation Analysis}

According to Preacher and Hayes (2004), the mediating effect should be tested by conducting a bootstrap process: sampling the distribution of the indirect effect which works for simple and multiple mediator models. Bootstrapping makes no assumptions about the shape of the variables distribution and it can be applied to small sample sizes as well (Preacher \& Hayes, 2004). 
Indirect Effect Hypothesis $(7,8)$

\begin{tabular}{|c|c|c|c|c|c|}
\hline Relationship & Path Co. & St. Er. & P-value & Indirect Effect & $95 \% \mathrm{CI}$ \\
\hline \multicolumn{6}{|l|}{ IV to Mediators (a) } \\
\hline $\mathrm{IC} \rightarrow \mathrm{CP}$ & 0.92 & 0.023 & 0.000 & & \\
\hline PEU $\rightarrow$ CP & 0.91 & 0.040 & 0.000 & & \\
\hline \multicolumn{6}{|c|}{ Direct Effects of Mediators on DV (b) } \\
\hline $\mathrm{CP} \rightarrow \mathrm{CS}$ & 0.17 & 0.089 & 0.040 & & \\
\hline $\mathrm{CP} \rightarrow \mathrm{CS}$ & 0.42 & 0.050 & 0.000 & & \\
\hline \multicolumn{6}{|c|}{ Total Effect of IV on DV (c) } \\
\hline $\mathrm{IC} \rightarrow \mathrm{CS}$ & 0.93 & 0.026 & 0.000 & & \\
\hline PEU $\rightarrow$ CS & 0.99 & 0.030 & 0.000 & & \\
\hline \multicolumn{6}{|c|}{ Direct Effect of IV on DV (c') } \\
\hline $\mathrm{IC} \rightarrow \mathrm{CS}$ & 0.76 & 0.086 & 0.000 & & \\
\hline PEU $\rightarrow$ CS & 0.61 & 0.053 & 0.000 & & \\
\hline Indirect Effect(H7) & & & & 0.164 & \\
\hline Indirect Effect(H8) & & & & 0.384 & \\
\hline $\mathrm{IC} \rightarrow \mathrm{CP} \rightarrow \mathrm{CS}$ & & 0.094 & & & $.022, .353$ \\
\hline $\mathrm{PEU} \rightarrow \mathrm{CP} \rightarrow \mathrm{CS}$ & & 0.058 & & & $.268, .498$ \\
\hline
\end{tabular}

As presented in Table 5, the bootstrapping analysis indicates that the path coefficient of indirect path IC $\rightarrow \mathrm{CP} \rightarrow \mathrm{CS}$ reported, 0.164, is not significant with CI: ($0.022,0.353)$. Thus, it can be concluded that the mediation effect of $\mathrm{CP}$ is not statistically significant in relation between IC and capital structure. Also, the bootstrapping analysis for $\mathrm{H} 8$ indicated that the path coefficient of indirect path $\mathrm{PEU} \rightarrow \mathrm{CP} \rightarrow \mathrm{CS}$ was reported as 0.384 and that is significant with CI: $(0.268,0.498)$. Thus, it can be concluded that the mediation effect of $\mathrm{CP}$ is statistically significant in relation between PEU and capital structure. It shows that the relation between PEU and CS is a fully mediated relationship through the contributions of $\mathrm{CP}$.

\section{Intellectual Capital and Values}

The World Values Surveys were designed to measure all major areas of human concern, from religion to politics to economic and social life (Inglehart \& Welzel, 2005). It turns out that two dimensions dominate the picture: (1) Traditional vs. Secular-rational values and (2) Survival vs. Self-expression values. These two dimensions explain more than 70 percent of the cross-cultural variance on scores of more specific values. The Traditional/Secular-rational values dimension reflects the contrast between societies in which religion is very important and those in which it is not. The second major dimension of cross-cultural variation brings a polarization between Survival and Self-expression values. Thus, priorities have shifted from an emphasis on economic and physical security above all, toward an increasing emphasis on subjective well-being, selfexpression, and the quality of life (Inglehart and Norris, 2003; Inglehart and Welzel, 2005).

Inglehart and Norris (2003) and Inglehart and Welzel (2005) have noted correlations between self-expression values and GDP growth at the national level. In detailed research tracking more than 60 countries over four decades, the above-mentioned authors identify tolerance or what is called 'self-expression' to be a core element of a new values system associated with higher levels of GDP and economic growth. Psychological studies (Sternberg, 1999; Fredrickson, 2001) indicate that self-expression is associated with higher levels of creativity, innovation, and entrepreneurial behavior.
Lucas (1988) explicitly notes the similarities in values and orientation as 'creative' actors between technological and entrepreneurial labor and artistic and cultural populations. Self-expression values are associated with higher levels of creativity, innovation, entrepreneurial behavior, and human capital; these values are ones that staff emphasizes over the submission of skills, know-how, and expertise. Selfexpression values increase employee competence for resolving professional difficulties and for managing intellectual capital. Human capital also considers how effectively a business exploits its individual employee's capital as measured by creativity and innovation. Selfexpression can provide greater efficiency and scalability in relational capital (customer relationships, supplier relationships). Analyzing the actual value and the whole performance of intellectual capital's parts in the creative and innovative knowledge society is a fundamental part of business (Fredrickson, 2001). Currently, Iran conveys traditional and survival values according to the criteria of "Secular-rational values" and "self-expression values" as per the World Values Surveys. It can be claimed, on the basis of the aforementioned studies, that such a situation does not foster the development of the intellectual capital (See Appendix). The existing state of affairs in Iran substantiates this claim. However, now the situation has shifted slightly toward self-expression values. The shift from survival values to self-expression values is very slow in Iran.

Rational human capital, the reasonable value that the personnel of a corporate deliver through the request of efficient skills, know-how and knowledge for solving professional tasks and using its intellectual capital.

Currently Iran conveys traditional and survival values according to the criteria on of "Secular-rational values" and "self-expression values" as per World Values Surveys. It can be claimed, on the basis of the aforementioned studies, that such a situation does not foster the development of the intellectual capital (See the Appendix). The existing state of affairs in Iran substantiates this claim. However, now the situation has shifted slightly toward self-expression values. The shift from survival values to self-expression values is very slow in Iran. 


\section{Intellectual Capital Multiple Criteria Decision Support (ICMCDS) System}

Existing knowledge, neural networks, expert and decision support systems are all analyzed in order to determine the most efficient versions of intellectual capital. Hence, an ICMCDS system, consisting of a database, database management system, model-base, model-base management system, and user interface, was developed.

Intellectual capital (human capital, structural capital, relational capital, spiritual capital) involves a number of interested parties pursuing various goals as well as exhibiting different potentialities, educational levels, and experience. This diversity leads to various approaches of the above parties to decision making. In order to thoroughly analyze the alternatives available and to obtain an efficient compromise solution, it is often necessary to define them on the basis of economic, management, organizational, qualitative, legal, social, cultural, emotional, technical, technological, or other types of information. This information should be provided in a highly user-oriented manner. The presentation of information needed for decision making in ICMCDS system may be in conceptual (digital or numerical), textual, graphical (diagrams, graphs, drawing), photographic, aural, augmented reality, visual (video), and/or quantitative forms. Thus, quantitative information presentation involves criteria systems and subsystems, units of measurement, values and initial significances that fully define the variants provided. Conceptual information means a conceptual description of the alternative solutions, the criteria and ways of determining their values and significances, and so forth. In this way, an ICMCDS system enables the decision maker to obtain various conceptual and quantitative information on intellectual capital from a database and a model-base which will allow him/her to analyze the above factors and to make an efficient solution.

The following tables illustrate ICMCDS system database:

- Initial data tables. These contain general facts about the intellectual capital (human capital, structural capital, relational capital, spiritual capital).

- Tables assessing intellectual capital (human capital, structural capital, relational capital, spiritual capital) solutions. They contain quantitative and conceptual information about alternative intellectual capital solutions.

- Tables of multivariant design. They provide quantitative and conceptual information on the interconnection of the intellectual capital (human capital, structural capital, relational capital, spiritual capital) elements and possible combinations as well as data on complex multivariate design of intellectual capital.

To design the structure of a database and perform its completion, storage, editing, navigation, searching, browsing, and so forth, a database management system was used.

Since the efficiency of an intellectual capital variant is often determined taking into account different factors, a model-base of a decision support system should include models enabling a decision maker to do a comprehensive analysis of the variants available and to make a proper choice.
The following models of model-base are aimed to perform this function:

- a model of developing the alternative variants of human capital, structural capital, relational capital, and spiritual capital,

- a model for determining the initial weight of the criteria (with the use of expert methods),

- a model for the criteria weight establishment,

- a model for multivariant design of an intellectual capital,

- a model for multiple criteria analysis and setting the priorities,

- a model for determination of project utility degree,

- a model for text mining,

- a model for providing recommendations.

Based on the above models, an ICMCDS system can make up to 100,000 intellectual capital alternative versions, performing their multiple criteria analysis, determining the utility degree, and selecting most beneficial variant without human interference.

\section{Conclusion}

The research presented here confirms that the capital structure in Iranian companies needs to shift from tangible to intangible assets or IC, since it promotes productivity improvement and creativity that positively influence CP. In the current era of technological revolutions and knowledgebased economies, IC is known as an extremely important capital for the firms. Hence, firms should use IC to attain sustainable competitive advantages. This result matches those observed in earlier studies such as by Ahmadi et al. (2013), Abhayawansa and Guthrie (2014), and Ling (2013). During the recent years, Iran has attempted to shift financial policy in favor of domestic industry. The government has offered good conditions such as tax advantages and low interest rates to stimulate productivity. For this reason, most of the manufacturing companies have used more debt financing due to low interest rates. The environmental uncertainty of companies in Iranian market has increased rapidly due to the improvement in the rate of technological broadcasting and better globalization issues. This positive relation shows that companies have tried to adapt to this uncertain environment by adopting structures, systems, and strategies that allow flexibility, keep options open, and support rapid response capability. Thus, the consequence of being able to collect different information leads to better $\mathrm{CP}$ by generating more accurate perceptions of environmental conditions and by choosing appropriate strategies to support the firm's ability to achieve higher performance. These steps contribute to the company being able to withstand challenges and to survive in higher uncertainty environments. Results demonstrate that there is not a significant relationship between PEU and capital structure in the context of Iran, because during recent years, manufacturing companies are operating in uncertain environments without accurate information; this situation makes it more difficult for managers to evaluate accurately the appropriateness of decisions. This argues for the increased need for debt financing in more dynamic and uncertain environments to reduce transaction costs. In the highly unpredictable market environment of Iran, the present and 
future value of assets and products are uncertain for managers, so if the company wants to continue with highly specialized production equipment, or retain highly skilled workers to increase its profitability or economic value creation, it has to increase its assets specificity by increasing the cost of the transaction. Thus, in this situation debt could be considered as an attractive alternative. This finding seem to be consistent with other research such as reported by Gleason et al. (2000) which conducted surveys in Europe and by De Jong et al. (2008) which analyzed capital structure for 42 countries around the world.

Regarding the highly uncertain environment of Iran, managers are not certain about the future, nor can they predict how regulatory changes will affect their activity. Unpredictability, in terms of the future demand for products, the rate and direction of technological changes, competitors' behavior, and future value of an asset, will increase the risks associated with equity financing. Based on the findings of this study, managers decided to rely more on their intangible assets. This means that the focus of Iranian manufacturing in terms of capital structure decision making has shifted from tangible assets to intangible assets, although they did not consider its influence on performance. Iranian manufacturing industries have hired highly educated employees and they don't have to pay for training issues. This result indicates that the interactions between the firm's value and financial policy of the firm are guaranteed by some features of resources and capabilities (Belás et al., 2016). The involvement of CP implies that in Iranian manufacturing firms, managers have designed a variety of activities to manipulate their environment in their favor.

However, the mediating effect of $\mathrm{CP}$ confirms that each company has to decide on the strategies and organizational forms that would enable them to operate in the external environment to earn the expected profit. An organization's strategy reflects the most critical elements of its environment. Iranian managers have improved their organization's flexibility and ability to adapt to continual environmental changes. Therefore, it can be concluded that in Iranian manufacturing companies, managers cope with changes in their firm's external environment by choosing an appropriate structure and design of a matching strategy. A comparison of the finding with those of other studies confirms direct and indirect impact on capital structure is because of the influence of country-specific factors and firm-specific factors in different countries.

These results broadly support the work of other studies in this area such as Lisin et al. (2015) and Streimikiene et al. (2016). This research study calls the attention of managers, stakeholders, and top management such as the Board of Directors to design efficient capital structure in Iran. This study is useful for policymakers to set some rules and regulations for investor protection and to encourage them to invest more in the capital market. Because of unstable economy and heavy sanctions, the government should set some compensation for companies to encourage them to participate more in capital markets, thereby making the market more competitive and creating more choices for companies to raise money. Further, this study may provide the basic data for future studies and stimulate further research on how to advance multi-dimensional studies in developing countries.

Theoretical limitations to this study are related to country factors. IC, PEU, and CP were affected by the special situation of Iran's economic and political crises; therefore, the findings of this study cannot be generalized to other countries. However, the authors believe that these principles are applicable to any situation. Additionally, research directions are discussed to mitigate the effect of the limitations. First, the future research should involve all companies in Iran involving both financial and non-financial firms. Second, the future research should involve different microeconomic uncertainty factors such as the inflation rate, gross domestic product, and real exchange rate and its influence on capital structure decision making. Furthermore, the traditional approach to understanding firms' choice of capital structure has been to consider firms' target ratio, internal financing, and external financing. This approach has not been very successful in terms of providing and understanding the capital structure firms choose in practice. Future research should incorporate the factors and indicators of many new securities in recent years which suggest the alternative approach of considering the optimal form of securities that firms should issue.

\section{Appendix}

(I) Country average scores on Traditional/Secular-rational and Survival/Self-expression values dimensions, 1995 (see http://www.worldvaluessurvey.org/wvs.jsp)

\begin{tabular}{|c|c|c|c|c|c|}
\hline$*$ & $* *$ & $* * *$ & $*$ & $* *$ & $* * *$ \\
\hline Albania & .52 & -1.56 & Hungary & .79 & -.77 \\
\hline Argentina & -.60 & .71 & India & -.54 & -.69 \\
\hline Bangladesh & -1.24 & -1.10 & Iran & -1.40 & -.34 \\
\hline Belarus & .67 & -1.72 & Japan & 1.79 & .37 \\
\hline Britain & .08 & 1.24 & Jordan & -1.46 & -.97 \\
\hline Bulgaria & .90 & -1.23 & Latvia & 1.33 & -.89 \\
\hline Chile & -.81 & -.08 & Lithuania & .96 & -1.45 \\
\hline China & .79 & -1.23 & Macedonia & .31 & -1.02 \\
\hline Croatia & .72 & -.51 & Mexico & -.81 & .30 \\
\hline Czech & 1.07 & .33 & Moldova & .36 & -1.91 \\
\hline Estonia & 1.27 & -1.30 & Nigeria & -1.58 & -.68 \\
\hline Finland & .68 & 1.01 & Pakistan & -1.39 & -.52 \\
\hline
\end{tabular}

\begin{tabular}{|l|}
\hline \multicolumn{1}{|c|}{$*$} \\
\hline Philipines \\
\hline Poland \\
\hline Romania \\
\hline Russia \\
\hline Serbia \\
\hline Slovakia \\
\hline Slovenia \\
\hline Spain \\
\hline Sweden \\
\hline Turkey \\
\hline Ukraine \\
\hline USA \\
\hline
\end{tabular}

\begin{tabular}{|r|}
\hline \multicolumn{1}{|c|}{$* *$} \\
\hline-1.38 \\
\hline-.47 \\
\hline .36 \\
\hline .87 \\
\hline .84 \\
\hline .41 \\
\hline .69 \\
\hline-.37 \\
\hline 1.49 \\
\hline-1.13 \\
\hline .84 \\
\hline-.89 \\
\hline
\end{tabular}

\begin{tabular}{|r|}
\hline \multicolumn{1}{|l|}{$* * *$} \\
\hline-.12 \\
\hline-.41 \\
\hline-1.26 \\
\hline-1.85 \\
\hline-1.05 \\
\hline-.27 \\
\hline-.04 \\
\hline .47 \\
\hline 1.99 \\
\hline .28 \\
\hline-1.83 \\
\hline 1.62 \\
\hline
\end{tabular}

* - Country ** - Traditional vs. Secular-rational values *** - Survival vs. Self-expression values

Sign $+(-)$ indicates that a greater (lesser) rate corresponds to greater (lesser) positive effect for human capital and relational capital. 
S. Soheilirad, S. Sofian, A. Mardani, E. K. Zavadskas, A. Kaklauskas, J. M. Darvishvand. The Relationship between Non...

(II) Country average scores on Traditional/Secular-rational and Survival/Self-expression values dimensions, 2000 (see http://www.worldvaluessurvey.org/wvs.jsp)

\begin{tabular}{|c|c|c|c|c|c|}
\hline$*$ & $* *$ & $* * *$ & $*$ & $* *$ & $* * *$ \\
\hline Albania & .07 & -1.14 & Hungary & .40 & -1.22 \\
\hline Argentina & -.95 & .36 & India & -.52 & -.60 \\
\hline Bangladesh & -1.21 & -.93 & Iran & -1.22 & -.45 \\
\hline Belarus & .89 & -1.23 & Japan & 1.91 & .54 \\
\hline Britain & .29 & 1.31 & Jordan & -1.61 & -1.05 \\
\hline Bulgaria & 1.15 & -1.52 & Latvia & .72 & -1.27 \\
\hline Chile & -.87 & .12 & Lithuania & .98 & -1.00 \\
\hline China & 1.20 & -.93 & Macedonia & .12 & -.72 \\
\hline Croatia & .08 & .31 & Mexico & -1.47 & .53 \\
\hline Czech & 1.23 & .38 & Moldova & .46 & -1.69 \\
\hline Estonia & 1.27 & -1.19 & Nigeria & -1.53 & .28 \\
\hline Finland & .84 & .94 & Pakistan & -1.42 & -1.25 \\
\hline
\end{tabular}

\begin{tabular}{|l|}
\hline \multicolumn{1}{|c|}{$*$} \\
\hline Phillipines \\
\hline Poland \\
\hline Romania \\
\hline Russia \\
\hline Serbia \\
\hline Slovakia \\
\hline Slovenia \\
\hline Spain \\
\hline Sweden \\
\hline Turkey \\
\hline Ukraine \\
\hline USA \\
\hline
\end{tabular}

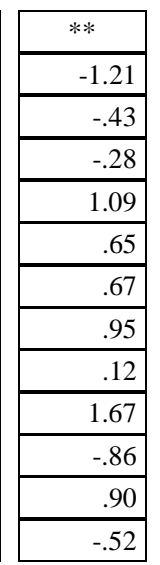

\begin{tabular}{|r|}
\hline \multicolumn{1}{|c|}{$* * *$} \\
\hline-.11 \\
\hline-.60 \\
\hline-1.60 \\
\hline-1.88 \\
\hline-1.03 \\
\hline-.43 \\
\hline .38 \\
\hline .51 \\
\hline 2.09 \\
\hline-.34 \\
\hline-1.72 \\
\hline 1.59 \\
\hline
\end{tabular}

* - Country ** - Traditional vs. Secular-rational values $* * *$ - Survival vs. Self-expression values

Sign $+(-)$ indicates that a greater (lesser) rate corresponds to greater (lesser) positive effect for human capital and relational capital.

\section{Reference}

Abdullah, D. F., \& Sofian, S. (2012). The Relationship between Intellectual Capital and Corporate Performance. Procedia - Social and Behavioral Sciences, 40, 537-541. doi: http://dx.doi.org/10.1016/j.sbspro.2012.03.227

Abdel-Kader, M., \& Luther, R. (2008). The impact of firm characteristics on management accounting practices: A UKbased empirical analysis, British Accounting Review, 40(1), 2-27. https://doi.org/10.1016/j.bar.2007.11.003

Abhayawansa, S., \& Guthrie, J. (2014). Importance of intellectual capital information: a study of Australian analyst reports. Australian Accounting Review, 24(1), 66-83. doi: 10.1111/auar.12012

Aftab, M., Ehsan, R., Naseer, S., \& Awan, T. (2012). The Effect of Corporate Strategy and Capital Structure on Performance of Banking Sector of Pakistan. Global Journal of Management and Business Research, 12(17).

Ahangar, G. R, Alimardani. K, Jahanian. KH, Faridnia. A, \& M, Mardi. (2012). Evaluation of domestic partner relationships and environmental uncertainty on degree of localization and performance of enterprises: The case of Iranian small and medium enterprises. African Journal of Business Management, 6(15), 5234-5242.

Ahangar, G. R. (2011). The relationship between intellectual capital and financial performance: An empirical investigation in an Iranian company. African Journal of Business Management, 5(1), 88-95.

Al-Ajmi, J., Abo Hussain, H., \& Al-Saleh, N. (2009). Decisions on capital structure in a Zakat environment with prohibition of riba: the case of Saudi Arabia. The journal of risk finance, 10(5), 460-476. https://doi.org/10.1108/15 265940911001376

Alipour, M. (2012). The effect of intellectual capital on firm performance: An investigation of Iran insurance companies. Measuring Business Excellence, 16(1), 53-66. https://doi.org/10.1108/13683041211204671

Al-Mawali, H. (2015). Strategic Management Accounting Usage, Environmental Uncertainty and Organizational Performance. Research Journal of Finance and Accounting, 6(11), 130-138.

Asiaei, K., \& Jusoh, R. (2015). A multidimensional view of intellectual capital: the impact on organizational performance. Management Decision, 53 (3), 668-697. https://doi.org/10.1108/MD-05-2014-0300

Attar, A. (2014). Corporate Strategy and Capital Structure: An Empirical Study of Listed Manufacturing Firms in Saudi Arabia. A Thesis submitted for the degree of Doctor of Philosophy. Brunel Business SchoolBrunel University. https://core.ac.uk/display/20572801

Awadallah, E. A., \& Allam, A. (2015). A Critique of the Balanced Scorecard as a Performance Measurement Tool. International Journal of Business and Social Science, 6 (7).

Babatunde, A. A. (2016). Empirical evidence on capital structure determinants in NIGERIA. Journal of Economics and International Finance, 8(6), 79-84. doi: 10.5897/JEIF2016.0754

Belas, J., Vojtovic, S., \& Kljucnikov, A. (2016). Microenterprises and Significant Risk Factors in Loan Process. Economics and Sociology, 9(1), 43-59.

Blackmon, V. Y. (2008). Strategic Planning and Organizational Performance: An Investigation Using the Balanced Scorecard in Non-Profit Organizations. Doctor of Philosophy. Capella University. 
Bontis, N. (1998). Intellectual Capital: An Exploratory Study that Develops Measures and Models. Journal of Intellectual Capital, 36 (2), 63-76. http://dx.doi.org/10.1108/00251749810204142

Bontis, N., Seleim, A., \& Ashour, A. (2007). Human capital and organizational performance: a study of Egyptian software companies. Management Decision, 45(4), 789-801. https://doi.org/10.1108/00251740710746033

De Jong, A., Kabir, R., \& Nguyen, T. T. (2008). Capital structure around the world: The roles of firm-and country-specific determinants. Journal of Banking \& Finance, 32(9), 1954-1969. https://doi.org/10.1016/j.jbankfin.2007.12.034

Delcoure, N. (2007), "The Determinants of Capital Structure in Transitional Economies", International Review of Economics and Finance, 16(2), 400-415. https://doi.org/10.1016/j.iref.2005.03.005

Dragnic, D. (2014). Impact of internal and external factors on the performance of fast-growing small and medium businesses. Management: Journal of Contemporary Management Issues, 19(1), 119-159. hrcak.srce.hr/1246 11 ?lang=en

Elbanna, S., \& Alhwarai, M. (2012). The Influence Of Environmental Uncertainty And Hostility On Organization Performance. UAEU-FBE-Working Paper Series ISSN 2079-7141.

Emadzadeh, N., Afzali, N., bagheri, A., Rahimpoor, M., Ezadi, F., \& Rahmani, M. (2013). Effect of Intellectual Capital on Firm Performance. International Journal of Academic Research in Accounting, Finance and Management Sciences, 3(2), 98-103. www.hrmars.com/admin/pics/1875.

Fredrickson, B. L. (2001). The role of positive emotions in positive psychology: the broadenand-build theory of positive emotions. American Psychologist, 56: 218-226. https://doi.org/10.1037/0003-066X.56.3.218

Galdeano-Gomez, E., \& Cespedes-Lorente, J. (2008). Environmental spillover effects on firm productivity and efficiency: An analysis of agri-food business in Southeast Spain. Ecological Economics, 67(1), 131-139. http://dx.doi.org/10. $1016 /$ j.ecolecon.2007.12.004

Gleason, K. C., Mathur, L. K., \& Mathur, I. (2000). The interrelationship between culture, capital structure, and performance: Evidence from European retailers. Journal of Business Research, 50(2), 185-191. https://doi.org/10. 1016/S0148-2963(99)00031-4

Graham, J. R., \& Leary, M. T. (2011). A review of empirical capital structure research and directions for the future. Annual Review Financial Economic, 3(1), 309-345. https://doi.org/10.1146/annurev-financial-102710-144821

Hair, F., Sarstedt, M., Hopkins, L., \& Kuppelwieser, V. (2014). Partial least squares structural equation modeling (PLSSEM) An emerging tool in business research. European Business Review, 26(2), 106-121. https://doi.org/10. 1108/EBR-10-2013-0128

Hillier, D., Grinblatt, M., \& Titman, S. (2008). Financial Markets and Corporate Strategy, European Edition, Mcgraw-Hill. Maidenhead.

Hoque, Z. (2005). Linking environmental uncertainty to non-financial performance measures and performance: a research note. The British Accounting Review 37 (2) 471-481. https://doi.org/10.1016/j.bar.2005.08.003

Inglehart, R., \& Norris, P. (2003). Rising Tide. New York and Cambridge: Cambridge University Press. https://doi.org/10. $1017 / \mathrm{CBO} 9780511550362$

Inglehart, R., \& Welzel, C. (2005). Modernization, Cultural Change and Democracy. New York and Cambridge: Cambridge University Press. https://doi.org/10.1017/CBO9780511790881

Ismail, M. B. (2005). The Influence of Intellectual Capital on the Performance of Telekom Malaysia. PhD Thesis, Universiti Teknologi Malaysia.

Jusoh, R. (2008). Environmental Uncertainty, Performance, and the Mediating Role of Balanced Scorecard Measures Use: Evidence from Malaysia. International Review of Business Research Papers, 4(2), 116-135.

Kaplan, R. S., \& Norton, D. P. (2001). Transforming the balanced scorecard from performance measurement to strategic management: part 1. Accounting Horizon 15 (1), 87-104. https://doi.org/10.2308/acch.2001.15.1.87

La Rocca, M., \& La Rocca, T. (2007). Capital structure and corporate strategy: An overview. Available at SSRN 1023461.

Li, Y., Wang, L., \& Liu, Y. (2011). Organizational learning, product quality and performance: The moderating effect of social ties in Chinese cross-border outsourcing. International Journal of Production Research, 49(1), 159-182. https://doi.org/10.1080/00207543.2010.508943

Ling, Y. H. (2013). The influence of intellectual capital on organizational performance-Knowledge management as moderator. Asia Pacific Journal of Management, 30(3), 937-964. https://doi.org/10.1007/s10490-011-9257-5 
Lisin, E., Rogalev, A., Strielkowski, W., \& Komarov, I. (2015). Sustainable Modernization of the Russian Power Utilities Industry. Sustainability, 7(9), 11378-11400. https://doi.org/10.3390/su70911378

Liu, Q., \& Wong, K.P. (2011). Intellectual capital and financing decisions: evidence from the US patent data. Management Science, 57(10), 1861-1878. https://doi.org/10.1287/mnsc.1110.1380

Lucas, R. (1988). On the mechanics of economic development. Journal of Monetary Economics, 22 , 3-42. https://doi.org/10.1016/0304-3932(88)90168-7

Mat Nawi, H. (2015). Determinants of capital structure in small and medium sized enterprises in Malaysia. Brunel University London.

Mehralian, Gh., Rajabzadeh, A., Sadeh, M. R., \& Rasekh, H. R. (2013). Intellectual capital and corporate performance in Iranian pharmaceutical industry. Journal of Intellectual Capital, 13(1), 138. https://doi.org/10.1108/146919312111 96259

Meihami, B., Varmaghani, Z., \& Meihami, H. (2014). Role of Intellectual Capital on Firm Performance (Evidence from Iranian Companies). International Letters of Social and Humanistic Sciences(12), 43-50.

Modigliani, F., \& Miller, M. (1963). Corporate income taxes and the cost of capital: A correction. American Economic Review, 53, 433-443.

Myers, B. W., \& Saretto, A. (2010). Union Strikes and the Impact of Non-financial Stakeholders on Capital Structure. Working paper, Purdue University.

Newman, A., Gunessee, S., \& Hilton, B. (2011). Applicability of financial theories of capital structure to the Chinese cultural context: A study of privately owned SMEs. International Small Business Journal, 0266242610370977.

Nimtrakoon, S. (2015). The relationship between intellectual capital, firms' market value and financial performance. Journal of Intellectual Capital, 16(3), 587-618. https://doi.org/10.1108/JIC-09-2014-0104

Norton, E. (1991). Capital structure and small growth firms. The Journal of Entrepreneurial Finance, 1(2), 161.

Porter, M. E. (1980). Competitive Strategy. Free Press: New York.

Pourkiani, M., Sheikhy, A., \& Samii Daroneh, M. (2014). Importance and Status of Intellectual Capital in Knowledge Economy. Indian Journal of Fundamental and Applied Life Sciences, 4(S4), pp. 512-518.

Preacher, K. J., \& Hayes, A. F. (2004). SPSS and SAS procedures for estimating indirect effects in simple mediation models. Behavior Research Methods, Instruments, \& Computers, 36(4), 717-731. quantpsy.org/pubs/preacher _hayes_2004.pdf. https://doi.org/10.3758/BF03206553

Rahimnia. F., Keyvanipoor. S., \& Moghadasian, M. (2014). Analysis of BSC perspectives as related to the alignment of environmental uncertainty and supply chain strategy, Benchmarking. An International Journal, 21(6), 903-916.

Rakshit, D., \& Chakrabarti, S. (2012). An Empirical Analysis of the Factors Influencing the financial performance of an apex cooperative bank: a case study. The MA Journal, 47(2), 197-200. icmai.in/Knowledge-Bank/upload/casestudy/2012/empirical-analysis.pdf

Rudez, H. N., \& T. Mihalic, (2007), "Intellectual Capital in the Hotel Industry: A Case Study from Slovenia", Available online at: www.sciencedirect.com, Hospitality Management, 26(2), 188-199. https://doi.org/10.1016j.ijhm. 2005.11.002

Sajedi, J., \& Talebian Nia, H. (2015). The Relationship between Intellectual Capital and Organizational Performance in Ministry of Sport and Youth. International Journal of Sport Studies, 5 (1), 69-73. ijssjournal.com/fulltext/paper11012016084945.pdf

Sekaran, U., \& Bougie, R. (2010). Research Method for Business, A Skill Building Approach. John Wiley \& Sons Inc: Singapore.

Simerly, R., \& Li, M. (2000). Environmental Dynamism, Capital Structure and Performance: A Theoretical Integration and an Empirical Test. Strategic Management Journal, 21(1), 31-49. https://doi.org/10.1002/(SICI)1097-0266(2 00001) $21: 1<31::$ AID-SMJ76>3.0.CO;2-T

Soheilirad, S., \& Sofian, S. (2016). A Proposed Model of the Mediating Effect of Strategic Management Accounting on The Relationship between Perceived Environmental Uncertainty and Firm Performance. International Journal of Research-Granthaalayah, 4(1), 231-239. http://granthaalayah.com/Articles/Vol4Iss1/30_IJRG16_A01_38.pdf.

Sternberg, R. J. (ed.) (1999). Handbook of Creativity. New York: Cambridge University Press. 
Stephen, T., Reed, K., \& Ly. K. (2014). Human resource involvement in developing intellectual capital. The Service Industries Journal, 34(15), 1219-1233, https://doi.org/10.1080/02642069.2014.942651

Streimikiene, D., Strielkowski, W., Bilan, Y., \& Mikalauskas, I. (2016). Energy dependency and sustainable regional development in the Baltic States-a review. Geographica Pannonica, 20(2), 79-87. https://doi.org/10.5937/ GeoPan1602079S

Survilaite, S., Tamosiuniene, R., \& Shatrevich, V. (2015). Intellectual capital approach to modern management through the perspective of a company's value added. Global Journal of Management and Business Research: Theory and Practice. Issn 1648-0627 / eIssn 1822-4202, JEL Classification: D83, G32, M21.

Tseng, K.-A., Lin, C. I., \& Yen, S. W. (2015). Contingencies of intellectual capitals and financial capital on value creation: Moderation of business cycles. Journal of Intellectual Capital, 16(1), 156-173. https://doi.org/10.1108/JC-042014-0042

Wahba, H. (2008). Does the market value corporate environmental responsibility? An empirical examination. Corporate Social Responsibility and Environmental Management, 15(2), 89-99. https://doi.org/10.1002/csr.153

Wang, Wing-Ying \& C. Chang, (2005), "Intellectual Capital and Performance in Causal Models: Evidence from the Information Technology Industry in Taiwan". Journal of Intellectual Capital, 6(2) 222-236. https://doi.org/10. $1108 / 14691930510592816$

Yung, Y. F., \& Bentler, P. M. (1994). Bootstrap-corrected ADF test statistics in covariance structure analysis. British Journal of Mathematical and Statistical Psychology, 47(1), 63-84. https://doi.org/10.1111/j.2044-8317.19 94.tb01025.x

Zin, N. M., Sulaiman, S., Ramli, A., \& Nawawi, A. (2013). Performance Measurement and Balanced Scorecard Implementation: Case evidence of a Government-linked Company. Procedia Economics and Finance, 7, $197-204$. https://doi.org/10.1016/S2212-5671(13)00235-9

The article has been reviewed.

Received in November, 2016; accepted in October, 2017. 